\title{
COMPLAINING EXPRESSIONS USED BY THE CHARACTERS IN THE MOVIE ENTITLED TWO WEEKS NOTICE: A PRAGMATICS STUDY
}

\author{
Firman Ramdani $^{1}$, Lia Maulia Indrayani ${ }^{2}$ \\ firman.ramdani82@gmail.com
}

PADJADJARAN UNIVERSITY

\begin{abstract}
The study of complaining expressions used by the characters in the movie entitled "Two Weeks Notice" has been done. The object of this study is utterances that contain complaining expression. The aims of this study are to analyze and describe strategies of complaint and their functions. This study employs a descriptive qualitative method. This study applies the complaint theory proposed by Trosborg (1995) and the context theory proposed by Mc Mannis et al (1987). The result of this study shows that all of complaint strategies according to Trosborg can be found in this movie, those are hint, annoyance, ill cosequence, indirect accusation, direct accusation, modified blame, explicit condemnation of the accused's action, and explicit condemnation of the accused as a person strategies. There are three functions of complaint found in this movie, those are to break a relationship or create a social distance among the participants, to maintain a relationship and fix a situation, and to show a negative feeling or share a specific negative evaluation.
\end{abstract}

Keywords: Speech acts; complaint strategies; complaint functions and context.

\section{A. INTRODUCTION}

For many linguists, a central concept in pragmatics is the observation that utterances perform actions, generally known as speech acts. Actions performed via utterances are generally called speech acts, and in English, are commonly given more specific labels, such as apology, complaint, compliment, invitation, promise, or request (Yule, 1996).

Complaint has been suggested as the expression of negative feelings relating to what speakers present as a complainable matter (Wijayanto et al., 2013). The act of complaining is in essence retrospective in that a speaker passes a moral judgement on something which (he/she believes) the complainee has already done or failed to do, or is in the process of doing (Trosborg, 1995: 311). Complaint is defined as an illocutionary act in which the speaker (the complainer) expresses his/her disapproval, negative feeling, etc, towards the state of affairs described in the proposition (the complainable) and for which he/she holds the hearer--the complainee/accused responsible, either directly or indirectly (Trosborg, 1995: 311-312).

A movie can cover many communication phenomena that occur in the real life, such as greeting, parting and complaining. A complaint is an expression of a person's disapproval or negative feeling towards someone or situation. It can naturally cause offence and highly threaten the social relationship between speaker and hearer. Based on these facts, a complaint contained in a movie needs to be studied. This study discusses strategies and functions of complaining expressions used by the characters in the movie entitled "Two Weeks Notice" using a pragmatics approach. 


\section{B. LITERATURE REVIEW \\ 1. Complaint Strategies}

Trosborg (1995: 315-320) sets up the complaint categories into: no explicit reproach, expression of annoyance or dissapproval, accusation and blame. Each category consists of one ore more strategies. The total of the strategies is eight strategies. Here are the categories including the strategies:

\section{a. No explicit reproach}

A complainer uses hinting strategies in which case the complainable is not mentioned in the proposition. In other words the complainer does not directly state that something is bad or offensive.

Strategy 1. Hint

Example: There was nothing wrong with my car yesterday.

\section{b. Expression of annoyance}

This strategy involves the expression of annoyance, dislike, and disapproval, relating to a certain state of affairs the speaker considers bad for him or her. The utterance may also express the bad consequences resulting from an offence for which the complainee is held implicitly responsible.

Strategy 2. Annoyance

Example: Oh dear, I've just bought it.

Strategy 3. Ill Consequence

Example: Oh damn it, I'll lose my insurance bonus now.

\section{c. Accusation}

Accusations are used by a complainer to establish the agent of a complainable. The complainer can ask the hearer questions about the situation or assert that he or she was in some way connected with the offence and thereby try to establish the hearer as a potential agent of the complainable (indirect accusation). Alternatively, the complainer can directly accuse the complainee of having committed the offence (direct accusation).

Strategy 4. Indirect Accusation

Example: You borrowed my car last night, didn't you?

\section{Strategy 5. Direct Accusation}

Example: Did you happen to bump into my car?

\section{d. Blaming}

A complainer presupposes that the accused is guilty of the offence. There are three levels that are identified with respect to the explicitness with wich the complainer formulates his/ her moral condemnation of the accused.. 
Strategy 6. Modified Blame

The complainer expresses modified disapproval of an action for whisch the accused is responsible.

Example: Honestly, couldn't you have been more careful?

Strategy 7. Explicit Condemnation of the Accused's Action

The complainer explicitly states that the accused's action is bad.

Example: How on earth did you manage to be so stupid?

Strategy 8. Explicit Condemnation of the Accused as a Person

The complainer explicitly states what is implicit at all other levels, that he/she finds the accused a non-responsible social member.

Example: Oh no, not again! You really are thoughtless.

\section{Directness Level of Complaints}

Complaints could be expressed at varying levels of directness ranging from hint and mild disapproval to severe challenges in which the complainee is explicitly declared incompetent and irresponsible as a social member (Trosborg, 1995). Trosborg (1995) establishes the scale of directness using these following criteria: Propositional content $(\mathrm{P})$, Complainer $(\mathrm{C})$ and Accused/complainee (A).

Five factors to determine the directnes level of a complaint are (Trosborg, 1995: 314-315):
a. P describes/does not describe the complainable thing.
b. C's negative evaluation of the complainable thing is implicitly or explicitly expressed.
c. The agentive involvement of A is implictly or explicitly expressed.
d. C evaluates A's action as bad implicitly or explicitly.
e. C evaluates A as a bad person implicitly or explictly

\section{Context}

The study of contribution of context to meaning is often called pragmatics (McManis, 1987: 197). Therefore, studying pragmatics cannot be separated from context. Context consists of four aspects (McManis, 1987: 197), those are physical (things that are physically seen in an utterance situation), epistemic (the same understanding of knowledge among participants), linguistics (the relation between on going utterance and the previous one) and social (the social relationship among participants) contexts.

The objectives of the study on complaining expressions used by the characters in the movie entitled "Two Weeks Notice" are to analyze and describe the types of complaint strategy used by the characters in this movie an to analyze and describe the function of each type of complaint strategy used in this movie.

\section{RESEARCH METHODOLOGY}

This study applies a descriptive qualitative method. A descriptive research focuses on collecting data, classifying, analyzing data, interpreting them, and making conclusion (Surakhmad, 1994: 147). Meanwhile, a qualitative research is defined as a research that focuses on discoursive things, such as transcript, document, interview result and nondiscoursive data (statue, monument, building design, photo, video, etc). 
The data in a study may appear in the form of discourse, sentence, clause, phrase, word, or even morpheme (Maxwell, 2005: 93). The source of data in this study is a movie entitled "Two Weeks Notice" and the script of this movie. Meanwhile, the data of this study are taken from the utterances of the characters in the movie that contain complaining expression.

Sampling implies the purpose of 'representing' the population sampled. The typical way selecting setting and individuals in qualitative research is purposive sampling. Selecting times, setting, and individuals that can provide you with the information that you need in order to answer your research question $\mathrm{s}$ is the most important consideration in qualitative sampling decisions (Maxwell, 2005: 88). This study employs a purposive sampling technique. The writer takes all the dialogues containing complaints in the movie, then, chooses the data which are considered to be representing the whole data, and takes them as the sample of this study.

In obtaining the maximum result of the research, the writer tries to explain each step of the descriptive research in accurate and detail (Surakhmad, 1994: 140). The procedure of this study is watching the movie several times, searching the script of the dialogues in the movie on the internet, collecting data that covers the utterances containing complaints, classifying the data based on the types of complaint strategies, choosing the representative data to be analyzed, analyzing and interpreting the data to answer the problem statements, drawing conclusion from the result of the analysis and giving suggestion.

The data are analyzed by describing the the context of situation in which the complaint occurs, classifying and analyzing the strategy of complaint used in the movie based on Anna Trosborg's theory, analyzing the character's purpose or function in employing complaint from the way the complainer uttering the complaint, drawing conclusion from the data analysis and giving suggestion.

\section{FINDINGS AND DISCUSSION}

The writer will only serve eight data found in the movie entitled "Two Weeks Notice," which represent all strategies of complaint. The data analysis is managed starting from the weakest strategy of complaint to the strongest one. The data analysis will cover the context, the strategy and the function of a complaint.

\section{Hint Strategy}

Description of Context:

The conversation takes place in Lucy's car. It happens between Lucy Kelson and George Wade. Lucy works for Wade Corporations as an attorney. George and his brother, Howard, are the owners of the company. Lucy and George are on the way of going home from a tennis event. George is driving the car and unfortunately, they are trapped in a traffic jam. In this conversation, Lucy admits to George that she has recently eaten too much of food. Then, she states her complaint.

Lucy : That last chili dog is really barking.

George : It's not a perfect timing, I must say. We'll be in the city in twenty five minutes. 
Analysis of Complaining Expression:

The complainer, Lucy, expresses her complaint by using a hint expression, "That last chili dog is really barking." It implicitly shows that she gets a stomachache and need to use a toilet immediately. It can be interpreted as, "she feels annoyed by her illness and wants George to find her a toilet immediately."

The complainer, Lucy, uses a hint expression to make the complainee, George, knowing the illness she feels. Since the complainee is the complainee's boss, the complainer does not want to be impolite in expressing the complaint. The complainer states a hint strategy to make the complainee helping her to fix the situation that she considers bad for her.

\section{Annoyance Strategy}

\section{Description of Context:}

The conversation happens between George Wade and Lucy Kelson via telephone. George is Lucy's boss. He is a very rich and good looking young man, and he is well-known as a plaboy. It is 2 o'clock in the morning. George is in a bar accompanied by a pretty young girl, and Lucy is sleeping in her bedroom. Then, Lucy's phone starts ringing.
Lucy : Hello.
George : : Yes, I'm glad you're up. I didn't want to wake you. I just felt like a chat.
Lucy : George, it is two o'clock in the morning. Can't you talk to whatever mensa candidate you're with?

Analysis of Complaining Expression:

In the conversation above, there are two complaints expressed by Lucy. The first is an expression of annoyance, "George, it is two o'clock in the morning." She expresses her annoyance by mentioning the time. It can be interpreted as, "It is two o'clock in the morning, so George should not have called her." This interpretation is strengthened by the second complaint, which is belong to an expression of indirect accusation strategy, "Can't you talk to whatever mensa candidate you're with?" The second one shows that the complainer does not want to talk with the complainee at the moment.

Annoyance, the first complaint, is categorized as a polite complaining expression. The complainer tries to soften her complaint by expressing indirect complaint. It can be concluded that the complainer does not want to break the relationship with the complainee. The complainer still cares with their relationship and only wants the complainee to fix his annoying attitude.

\section{Ill Consequence Strategy}

Description of Context:

This conversation is the continuation of the conversation in Hint Strategy. George makes a response to previous complaint. Lucy cannot accept George's response. Then, she utters her complaint.

George : It's not a perfect timing, I must say. We'll be in the city in twenty five minutes.

Lucy $\quad$ : I don't have a second! I feel I swallowed a cruise missile. 
Analysis of Complaining Expression:

The complaint, "I don't have a second! I feel I swallowed a cruise missile," is uttered by Lucy in an ill consequence expression. By stating, "I don't have a second!", she shows her dissatifaction with George's response. Then, it is followed by the expression of her illness, "I feel I swallowed a cruise missile." This complaint can be interpreted as, "she feels so sick and cannot hold it any longer."

After hearing George's response to Lucy's previous complaint, "It's not a perfect timing, I must say. We'll be in the city in twenty five minutes," Lucy feels dissatisfied. It can be concluded that she wants George to make a better response. She feels so sick with her condition and urges George once again to find a toilet for her. It means that the complainer wants the complainee to help her fixing the situation.

\section{Indirect Accusation Strategy}

Description of Context:

The conversation takes place in a church. It is the wedding of Lucy's best friend, Meryl. Lucy takes charge as the bridesmaid. She stands confidently beside Meryl. When the priest is in the middle of his speech, Lucy's phone rings so loud, and it breaks the humility of the ceremony. Everyone in the room turns their eyes to Lucy. Then, the bride, Meryl, utters her complaint.

Meryl : Is that yours?

Lucy : I'm so sorry. Please continue. Everyone looks so beautiful. Just keep going.

Analysis of Complaining Expression:

The conversation above happens between Meryl and Lucy. They are good friends. Everyone in the room feels annoyed by the sound of a phone ringing, which comes from Lucy's phone, especially Meryl. The complainer, Meryl, utters her feeling by stating a question to the complainee, Lucy, "Is that yours?" This strategy of complaint is categorized as an indirect accusation strategy.

By using a question to accuse that the complainee has caused an annoying situation means the complainer does not want to directly attack the complinee. Since, the participants here have a good relationship, the complainer does not want to break the relationship with the complainee. The complainer just wants the complainee to fix the situation by shutting her phone down.

\section{Direct Accusation Strategy}

Description of Context:

The conversation takes place in front of Wade Corporations building. It happens between George and Lucy. It is the first time they meet each other. George has just finished interviewing an applicant and come out of the building. He is on the way in going back to his hotel. Lucy comes there in purpose. She wants to negotiate the Wade's plan, to build new condominiums and to tear down the community center. She introduces herself and wants to talk further with George about her purpose. Then, George states his complaints. 
Ramdani \& Indrayani: Complaining expression...

George : Wait a minute. You're Kelson. You laid in front of our wrecking balls. You attacked the Zegman Brothers - - -

Lucy : I did not. It's not my fault they walked under a protest sign.

Analysis of Complaining Expression:

In this conversation, the complainer employs two direct accusations of complaining expression, "You laid in front of our wrecking balls. You attacked the Zegman Brothers." The complainer makes two accusations that the complainee has disturbed his business. By stating the word "you", the complainer directly addresses his complaints to the complainee.

This is the first time they meet each other. So, they are not bound with a particular relationship. The complainer does not care if his complaints can break their relationship, but he does not demand anything from the complainee. The complainer utters his complaints just to express his annoyance or negative feeling to the complainee.

\section{Modified Blame Strategy}

The conversation takes place in a meeting in Howard's office. It happens between Lucy, George and Howard. George and Howard are the owners of Wade Corporations, which is Lucy's workplace. It means that George and Howard are Lucy's bosses. Lucy desires to quit her job. But she is bounded with a very strict contract, which she made, that she cannot quit her job before the clauses in the contract fulfilled. The only way to get out of it is being fired. So, she tries to makes George and Howard deciding to fire her.

Lucy : : Good morning, boys. Sorry, I'm so late.

George : That's fine. We only just got here.

Howard : Forty-five minutes ago.

Analysis of Complaining Expression:

In the conversation above, it shows that Lucy comes so late for a meeting. She is sorry for her coming late. George respons her apology positively. But Howard cannot hide his dissapointment, since he is one of the owners of the company and Lucy is just an employee. So, the complainer, Howard, utters his complaint, "Forty-five minutes ago." By mentioning how long he and George have waited for Lucy, the complainer wants the complainee, Lucy, to know that the complainer feels very annoyed by the complainee's action. The complaint does not mention the proposition content and who is responsible for the complainable action. The complainer implicitly blames the complainee that she has made him waiting for fortyfive minutes. It can be concluded that the complaint is categorized as a modified blame strategy.

The complainee is a good asset for the company. She has done many valuable contributions for the company. Therefore, the complainer does not intend to break their professional relationship. The complainer does not mention any future obligation related to the complainee's action. Therefore, it can be concluded that the complaint is just intended to express the complainer's negative feeling to the complainee. 


\section{Explicit Condemnation of Accused's Action Strategy}

Description of Context:

The conversation takes place in Howard's house. It happens between two brothers of Wade's family, George and Howard. They are discussing about the company's plan. Howard utters his plan to knock down the community centerbuilding in order to build a new company's tower. George disagrees with the plan. He thinks that they should not do it, because they have promised the city to keep the community center building. Howard gives a reason to justify his plan that they will lose much money if they do not do it. Then, George also gives a reason to defend his argument.

George : Look, whatever we lose on this deal, I'm in for a half.

Howard : You'll be in for nothing at the rate you're going. Expensive divorces, poolside parties at the hotel for hundreds people including fireworks and a performance by Sting.

Analysis of Complaining Expression:

In the conversation above, the complaint, "You'll be in for nothing at the rate you're going," shows that the complainer, Howard, explicitly blames George for being a squanderer. The directness can be seen from the use of word "you." The complainer also states some facts to strenghten his complaints, "Expensive divorces, poolside parties at the hotel for hundreds people including fireworks and a performance by Sting." It can be concluded that the complaint uses an explicit condemnation of accused's action strategy.

The complainable things are the complainee's habit in wasting money and his disagreement to the complainer's plan. The complainer states the complaint to make the complainee changing his habit and agreeing the complainer's plan. Therefore, the function of this complaint is to repair the situation or to fix the complainee's attitude.

\section{Explicit Condemnation of the Accused as a Person Strategy}

Description of Context:

The conversation takes place outside the Wade Corporations' building. Lucy and George have just bought hotdogs for lunch. They are on the way of going back to their office. On the way, they pass a man in rusty clothes carrying a cup standing at the side of the street. Lucy puts a coin into his cup, because she thinks that she is a needy. Then, the man expresses a complaint.

A man in rusty clothes : : Hey, that's my coffee, you jerk! Lucy : Oh, sir, I'm so sorry.

Analysis of Complaining Expression:

In the dialogue above, the complainer, a man in rusty clothes, makes an open attack to the complainee, "Hey, that's my coffee, you jerk!" by using a swearing word, "jerk." The directness can be seen from the use of word "you." This complaint can be categorized as an explicit condemnation of the accused as a person strategy.

The complainer openly blames the complainee for making a bad attitude. Since the participants have no relationship, the complainer does not try to avoid a personal conflict 
Ramdani \& Indrayani: Complaining expression...

with the complainee. Therefore, it can be concluded that this complaint has a function to create a social distance.

\section{E. CONCLUSION AND SUGGESTION}

Based on the analysis, all of complaint strategies according to Trosborg can be found in the movie "Two Weeks Notice." Those are hint, annoyance, ill cosequence, indirect accusation, direct accusation, modified blame, explicit condemnation of the accused's action, and explicit condemnation of the accused as a person strategies. There are three functions of complaint found in this movie. They are to break a relationship or create a social distance between the participants, to maintain a relationship and fix a situation, and to show a negative feeling or share a specific negative evaluation.

It is suggested to other researchers to study the responses of the complaints in this movie or complaints and responses in other movies, dramas or debates.

\section{F. REFERENCES}

Maxwell, J.A. (2005). Qualitative Research Design: An Interactive Approach. California: Sage Publications Inc.

McManis, Carolyn .(1987). Language Files: Materials for an Introduction to Language. Ohio: Advocate Publishing Group.

Surakhmad, W. (1994). Pengantar Penelitian Ilmiah Dasar: Dasar, Metode, dan Teknik. Bandung: Tarsito.

Trosborg, Anna. (1995). Interlanguage Pragmatics: Requests, Complaints and Apologies. New York: Berlin: Mount de Gruyter.

Wijayanto, Agus., Laila, Malikatul., Prasetyarini, Aryati., \& Susiati, Susiati. (2013). Politeness in Interlanguage Pragmatics of Complaints by Indonesian Learners of English. English Language Teaching; Vol. 6, 188-201. Canadian Center of Science and Education. http://dx.doi.org/10.5539/elt.v6n10p188

Yule, George. (1996). Pragmatics. Oxford, New York: Oxford University Press. 